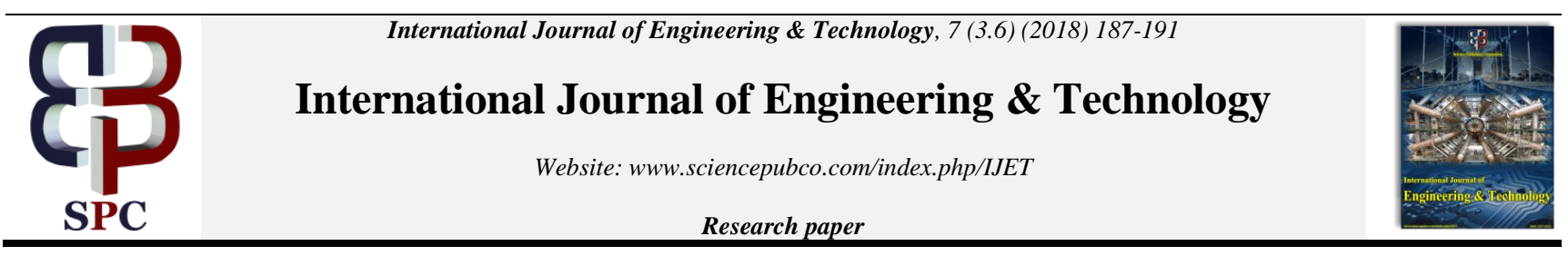

\title{
Teaching Literature Enhances Communication Skills - a Study with Special Emphasis on Poetry
}

\author{
M. Ilankumaran ${ }^{1 *}$, P. Deepa ${ }^{2}$ \\ ${ }^{1}$ Professor, Department Of English, Noorul Islam Center For Higher Education, Kumaracoi, Kanyakumari District, Tamil Nadu, India. \\ ${ }^{2}$ Assistant Professor, Department Of English, Noorul Islam Center For Higher Education, Kumaracoi, Kanyakumari District, Tamil \\ Nadu, India. \\ *Corresponding Author E-Mail:Mikumaran@Yahoo.Com
}

\begin{abstract}
The term communication is one of the most analyzed terms in the academic arena and it has been studied systematically since ancient times. Communication is an everyday social activity that is an essential and inherent component of every human being. It is a key to human development because the quality of the existence is linked directly to the quality of the communication. This article focuses on how literature in general and poetry in particular enhances the communication skills of the students. Every literary person knows about language and literature. However, they are most common to learn the vocabulary. Literature plays a key role in language classroom. It provides not only pleasure to readers but also builds experience and creates thinking ability. Moreover, literature has several literary forms such as prose, poetry, drama, novel, short stories, etc. Though there are several forms in literature, the most interesting genre is poetry. Poetry can be the works of great beauty due to its meter and rhyme scheme like the ebb and flow of an ocean. This really helps the student to show more involvement towards poetry. On the other hand, the students can try to know more vocabulary from the lines of the poems. Through different terms of poetry used in the classroom, the students get more benefits of knowing new terms and words.
\end{abstract}

Keywords: Communication skills, literature, poetry, literary terms, vocabulary, phrases, prose, language teaching.

\section{Introduction}

Communication is a skill that can be used to receive and transmit information from one person to another. English communication is a skill that can be perfect only through constant practice and continuous exposure to the target language. This skill is useful to widen the understanding capability of the students. If the person wants to achieve the goal, he has to communicate effectively with others. Communication can be improved through different methods. One of the methods is listening to literature especially poetry as a genre. Literature is important in day to day life because it connects individual thoughts and opinions. Moreover, it helps to show a way for record the thoughts of the human. It also helps to see life from the perspective of another person. Poetry is a compact language that expresses complex feelings. It gives pleasure to the readers. It develops the speaking skills of the students. It is a tool that can be worked according to the mood of the students. It promotes feelings and thoughts about the complex social issues.

Poetry plays a major role in language teaching. Poetry is an authentic material; it helps the student to promote the comprehension of the language that they are trying to master. The focal aim of the researcher is to progress the verbal communication of the students by teaching poetry in the classroom.

\section{Literature Review}

Classroom is the best place to learn language. Activities can be given to the students to develop speaking skills. Irina Chireev,
(2015) points out that "Teaching is no longer about mere broadcast of knowledge from teacher to students rather than increasing student's skills in real life situations. In classroom the students receive knowledge from teachers. The aim of developing speaking skills in English has always presented itself as a challenge to teachers of all ages.

The students - centered activities those truly helped to motivate and encourage secondary level learners to use the language as a tool for communication".

Poetry makes great changes in English Language Teaching. It always awakens our senses, promotes, literary knowledge. Poetry is musical and rhythmic so it catches everyone's attention. It is an interesting area where students learn more vocabulary. According to Reena Mittal,(2014) "Poetry develops an understanding of texts and their use in language classroom. Use of grammar is not easy for Non English background students but they too can exercise it will in poetry.

We must not forget our oldest technique 'Narrative' in which tales were sung by people who are not literate even, but their compositions were par excellence. Even Homer's Ilaid and odyssey were also written in this form and they are unparalleled even now. Similarly 'Shi' in China and 'Tanka' in Japan are still popular as they are unrhymed poetic compositions which impart knowledge poetically to all".

In the process of speaking the language fluently, the learner has to be motivated by the teacher. It provides exposure to real language; it can relate to the learners need more closely with a more creative approach and have a positive effect on the learner's motivation. Poetry is an important genre for the literature students through this they can understand the significance of figures of speech. It is the sophisticated literary tool and it works on the mood of the students. 
Sachin L. PatkiAdarsh (2013), argues that "The students have to learn how to speak the language efficiently .They are confident enough to speak the language; through practice they will improve their speaking skills.

Traditional methods for teaching English courses at the postsecondary level employ a lecture format of instruction in which majority of students are passively listening to the instructors. Teachers can have activity based poetry classes to enrich the speaking skills.

They can create an atmosphere for the students to be wholly involved in the activity by showing pictures to introduce the topic. Instead of reciting the poetry simply, teachers can have some kind of dramatization of the poetry".

Poetry promotes the development of feeling and induces the reader to think creatively. It can also be dramatized in the classroom to make students more interesting. In this review the author explains about dramatization of the poems and gets the positive output from the students.

According to Stephen Elting and Arthur Firkins (2006) "ELL can explore the aesthetic function of language and more widely, develop confident in using English as a communicative tool through the dramatization of poetry.

It is the rich language resources available to the English Language Learner and as such argues that reading, interpreting and performing poetry should be a central pedagogical feature of the English programme. Poetry enables the exploration of sound, image and word association while extending the semantic resources available to students ".

In the approach to performing poetry, the students have to think of how to bring the concept of the poem before the audience. From this, the listener is able to understand the different nonverbal communication in teaching the poem from the page to the stage.

\section{Methodology}

The researcher conducted an experimental research in classroom through a series of activities such as short speeches. A sample survey was conducted to collect the data on the basis of random sampling from the II year UG students from selected colleges in Kanyakumari district. The teacher can develop the language skills of the students by teaching literature, especially poetry. In order to assess the apprehension level of the students of Arts and Science Colleges and to make the study effective, 120 students of different disciplines were taken for research.

\section{Research objectives}

- To study the importance of poetry

- To learn different figures of speech

- To analyze the effectiveness of introducing short speeches in the classroom

- To introduce recommendations to use short speeches

Sample Size: The sample consists of 120 students

Tool: A questionnaire consists of 6 questions

\section{Teaching Poetry}

Poetry gives feelings, emotions, ideas and at the same time it gives pleasure to the readers. It is beneficial to improve the language. The involvement of students can be shown towards poetry only by the way of teaching. The teacher has to give chance to dramatize the poem at least once in a week. A teacher's role is important as for as poetry classrooms are concerned. The teacher has to suggest some points in the classroom to develop the knowledge of poetry to the students. They are:

a) The teacher has to begin a poem by a different poet in each class. b) The students have to memorize the poems and then recite them from memory.

c) The students need to create their own anthology of favorite poems.

d) The teacher has to introduce a new poetic word and make the students to give examples.

e) The teacher has to give list of words and ask them to create a poem using the words.

f) The students may be asked to decorate the classroom with illustrated poems, quotes and pictures of poets.

g) The teacher has to organize a poetry contest for students to enhance their knowledge.

h) The teacher has to ask literary terms from the poem that he/she used many times in the classroom.

Poetry is musical and rhythmic, so it catches every one's attentions.

It is a vehicle for expression on a wider horizon. Language of poetry can be single or ornamental; it can develop the creative talent of the students.

According to Ilankumaran, (2015) "Creative thoughts can lead to learning languages effectively.

Thoughts make a mind registered with images which are known as ideas". That is the reason, children can also be enjoyed in the smaller classes itself.

First of all, the teacher has to be aware how much the students know about poetry and its form, construction, rhyme and rhythm, only based upon that the teacher has to infuse the students to make them involved into poetry.

It also works for the encouragement of language because it ;

a) Enriches vocabulary.

b) Sound rhythm stress.

c) Creates aesthetic sense.

d) Pronunciation and fluency.

There are different methods which can be used by the teacher to develop the communication skills. They are:

- Dramatize the Poem

A literary piece needs to be given in the classroom, like an epic poem into a drama for presentation on the stage. The teacher has to allot time to the students for preparation. Props and costumes ought to be used as these are the things to develop the poem. If the class is small in size, ask the students to work together as one group, but each will have to be scored.

- Poems tell Stories

Some poems have stories like novel and drama. So the teacher has to instruct the students to convert the poem into short stories based on the interpretation of the poem. This method helps the students to learn comprehension and writing skills.

- Implement a Poem Recitation in the Classroom This is one of the best methods to memorize the poetic lines. The teacher instructs the students to recite the poem at least once in a week. While conducting such type of classes, the memory power of the students can be exhibited.

- Do not read a poem and only provide your own interpretation

The teacher has to give chances to speak English in the classroom Then only the students can come forward and share their own ideas and views. This makes them to share their points without any inhibition.

The teacher has to take the following steps to involve the students into poetry.

a. The teacher has to teach the lessons prepared by the students to a whole group or small group.

b. The teacher has to prepare the students to write the weekly test.

c. The teacher has to communicate only in English with the students.

d. The teacher has to make the students to frame sentence from the poetic words. 
e. The teacher needs to give chances to the students to write any haiku as their wish.

\section{Developing Communication Skills Through Teaching Poetry}

Poetry is the genre in literature which impresses everyone. Students can develop their communication skills by learning new methods in poetry. As there are different figures of speech, literary terms, literary forms are there in poetry, it makes the students to show more interest towards poetry. Such a beautiful language cannot be found in other genres except poetry.

The figurative use of language is another important beauty of poetry. Such figurative language is not only common in poetry but also it can be used in prose and nonfiction as well, but the real life can be seen only in poetry. Some of the figurative languages are often used in poetry. They are: Allegory, Metaphor, Simile, Hyperbole, Alliteration, etc. There are many terms used in poetry of which the researcher has mentioned only few. These give beauty to the poetic language and such terms could not be found in other genres like prose, drama or novel, etc. in literature Students have to learn more new terms when they read poetry. It creates the imaginative power of the students. It employs language to evoke and exalt special qualities of life. Poetry is one of the most effective and powerful transmitters of culture.

\section{Benefits of Using Poetry to Language Teaching}

Poetry is useful to develop the creative talent of students. It can play a key role to language teaching. The inclusion of poetry in language teaching has some benefits pertaining to language acquisition. They are:

- Poetry promotes critical thinking skills.

- It helps the students to go beyond the surface meaning.

- It makes the students feel comfortable and free.

- It enhances language development and stimulates their imagination.

- It develops oral and written language of the students.

- It gives pleasure to the students.

- It is memorable than prose because of its arrangement of rhyme scheme.

- It also helps in learning in sentence patterns because of repetition of certain patterns in a poem.

Poems are often rich in multiple layers of meaning and can be effectively used for discussions and sharing feelings or opinions It motivates pronunciation, intonation and articulation of the students. Mathew Arnold defines, "Poetry is simply the most beautiful, impressive, and widely effective mode of saying things and hence its importance". The task of the language teacher is to identify, select and use authentic poems to develop the language skills of the students to cater to the needs and expectations of the readers.

The language ability of student's can be improved only through conversation. Communication plays a main role in the day to day life. So without this skill it is really impossible to select any job. The entire field in the world either managerial or administrative needs communications. Good communication skills make the students not only to seek a better job but also to sustain in that. If the students are well and good in communication, they can survive anywhere without tension and fear.

\section{Analysis of Poetry}

\section{Shall I Compare Thee to A Summer's Day? -William} Shakespeare
The poem taken for analysis is Shakespeare's Sonnet 18 Shall I compare thee to a summer's day? William Shakespeare has written 154 sonnets. The researcher has chosen Sonnet18 for analysis because such a poem can be given in the classroom for conducting short speeches for the II year part two English students to enhance their language ability. The students can share more points about the theme of the sonnet and also they can memorize and recite the lines at the time of presentation. This is useful to develop the memory power, the innovative talent and also the students can learn new words and phrases.

A sonnet is the short poem of fourteen lines. Shakespeare's sonnets follow the pattern 'ababcdcdefefgg'. The author has used various images to highlight the never ending and everlasting beauty of his lover. The speaker is wondering to compare the lover with the summer's day. The poem starts with the line;

Shall I compare thee to a summer's day?

Thou art more lovely and more temperate

Rough winds do shake the darling buds of May,

And summer's lease hath all too short a date:

Sometimes too hot the eye of heaven shines,

In the second line of the sonnet, the speaker differentiates two things i.e., 'lovely' and 'temperate'. Shakespeare explains that both are powerful than summer's day. The speaker compares the beauty of his beloved to the summer season. As long as men continue to live, or eyes can see and as long as the poet's immortal lines live in this world, his beloved also will be remembered. The poem tempts the students to be active in participating short speeches. The last quatrain of the sonnet tells how the beloved differs from the summer in that respect his beauty will last forever.

And often is his gold complexion dimm'd;

And every fair from fair sometime declines.

By chance or nature's changing course untrimm'd;

But the eternal summer shall not fade

Nor lose possession of that fair thou owest

The above lines explain that the lover of the speaker is completely different from summer season because the season can end whereas the love is immortal. The sonnet deals with the theme of immortalization. Shakespeare is mocking the over-flowery language in sonnet 18.The beloved's beauty can coexist with summer, and indeed is more pleasant, but it is not a replacement for it. The students can create more ideas about the theme of the sonnet.

Nor shall Death brag thou wander'st in his shade,

When in eternal lines to time thou growest;

So long as men can breathe or eyes can see,

So long lives this and this gives life to thee.

As summer is occasionally short, hot, and rough, summer is in fact not the height of beauty for this particular speaker. This sonnet tells about the everlasting love and beauty of his friend. The concluding lines of the sonnet explain that the course of changing season makes every fair objects of nature lose its beauty. The teacher has to motivate the students to speak on the concept or theme of the poem.

Through these short speeches, the language skills of the students can be improved. Questions can also be asked for the betterment of the students' knowledge.

a. According to Shakespeare how summer season is different from other seasons. Discuss.

b. Who is being compared to a summer season? Discuss your own opinion with your classmates.

c. Do you have the experience of falling in love during your school days? Share your experience.

d. What is your perception about the speaker's love? Discuss. 


\section{Analysis of Data}

The questionnaire comprising six questions is used as a tool. All the questions are related to Short Speeches. Each statement has five options to be chosen. They are - Strongly agree, Agree, Neutral, Strongly disagree, Disagree. The outcome of the survey is discussed with the help of the following Table 1 using different variables.

Table 1: Responses Regarding Participation in the Short Speeches

\begin{tabular}{|l|c|c|c|c|c|c|c|}
\hline $\begin{array}{c}\text { Sl. } \\
\text { No. }\end{array}$ & Variables & $\begin{array}{c}\text { Strongly } \\
\text { Agree }\end{array}$ & Agree & Neutral & Disagree & $\begin{array}{c}\text { Strongly } \\
\text { Disagree }\end{array}$ & Total \\
\hline $\mathbf{1 .}$ & $\begin{array}{c}\text { Short Speeches } \\
\text { improve } \\
\text { confidence } \\
\text { level }\end{array}$ & 30 & 17 & 21 & 20 & 32 & 120 \\
\hline $\mathbf{2 .}$ & $\begin{array}{c}\text { Feel reluctance } \\
\text { to frame } \\
\text { sentences }\end{array}$ & 45 & 12 & 22 & 21 & 20 & 120 \\
\hline $\mathbf{3 .}$ & $\begin{array}{c}\text { Learn } \\
\text { vocabulary } \\
\text { through } \\
\text { listening }\end{array}$ & 35 & 25 & 15 & 10 & 35 & 120 \\
\hline $\mathbf{4 .}$ & $\begin{array}{c}\text { Enhance the } \\
\text { thinking } \\
\text { capability }\end{array}$ & 20 & 30 & 25 & 10 & 35 & 120 \\
\hline $\mathbf{5 .}$ & $\begin{array}{c}\text { Short Speeches } \\
\text { develop } \\
\text { anguage of the } \\
\text { students }\end{array}$ & 20 & 40 & 20 & 15 & 25 & 120 \\
\hline $\mathbf{6 .}$ & $\begin{array}{c}\text { Short Speeches } \\
\text { make students } \\
\text { know about } \\
\text { literary terms }\end{array}$ & 31 & 20 & 25 & 17 & 27 & 120 \\
\hline
\end{tabular}

Table 1: 1indicates that the students of part II English are good at presenting short speeches. In the tabular column given above, the different responses regarding participation in the short speeches are mentioned. Among 120 respondents, 30 students strongly agree, 17 agree, 21 are neutral, 20 students disagree and 32 students strongly disagree. This is taken into account that only less number of students has confidence in delivering speeches. The reason is majority of the respondents are from poor background and they are from villages. With regard to framing sentences some of the students are reluctant to frame sentences.45 students strongly agree, 12 students agree, 22 students are neutral whereas 21 disagree and 20 strongly disagree. This data prove that the students feel difficult to frame sentences due to lack of practice at school level. Unlike the above mentioned sect, there are students who are comfortable while participating in short speeches. Students can learn plenty of vocabulary through short speeches.35 students opted for strongly agree, 25 for agree, 35 students for strongly agree, 15 students are neutral and 10 students disagree. From this result, it is evident that the respondents are equally for and against the criterion. The fourth variable pertains to enhancing the thinking capability in an innovative way. This variable proves that the capability of students has increased by short speeches. 20 students strongly agree, 30 agree, 25 students are neutral,10 students disagree and 35 are strongly disagree. The students feel reluctant because of shyness and inhibition.

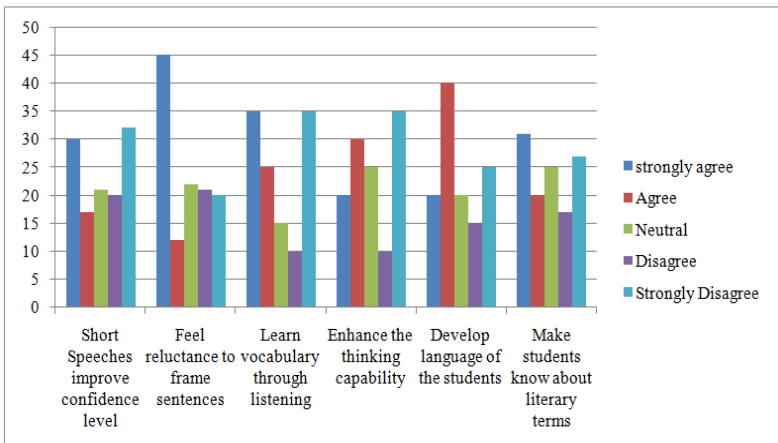

Figure 1: Responses regarding participation in the short speeches are neutral, 15 disagree and on the contrary, 25 students strongly disagree. To sum up, the higher number of the students who support disagree can improve the language ability through Short Speeches. The last variable of Short Speeches helps the students know about literary terms. Out of 120 respondents, 31 students strongly agree, 20 students agree, 25 are neutral,17 disagree that they are comfortable to learn more literary terms 27 strongly disagree that they are not at all interested to know new terms in participating in short speeches.

\section{Materials}

The respondent taken for analysis is part II English students. The teacher distributed the questionnaires to the students to collect data. The students have to complete the answer within five minutes that included the area Short Speeches. It contains six questions. The maximum time was given, and the sheets were collected.

\section{Analytical Framework}

The teacher has to collect the data in the form and examine questionnaire and the same should be placed in the research study.

\section{Speaking ACTIVITIES}

The teacher can give more activities for the enhancement of the students in the classroom. One of them short speeches. The researcher has chosen short speeches for analysis.

\section{Short Speeches as an Activity}

Short Speeches help the students to improve the confidence level of the language skills. By implementing such activities in the classroom, the students will become active participants. This type of activities makes them to get rid of fear, shyness, and hesitation.

\section{Findings and Suggestions}

The paper focuses on the need to build up the communication skills of the students through teaching literature. Shakespeare's sonnet "Shall I compare Thee to the Summer's Day?"has been taken for analysis. Students' can improve the speaking skills by discussing and delivering the poem in short speeches. This helps to improve the memory power of the students. They can develop not only their spoken ability but also their written ability. Incorporating literature in language can make the students lively and motivating. Poetry makes the students more imaginative than any other genre.

In every class, the role of teacher's is also indispensible; they have to pre-plan about the way how the poem can be conducted before entering the classroom. Teachers have to adopt different innovative methods to teach poetry in the classroom. Poetry not only portrays but also enlightens human life. Some of the suggestions for the students toup hold their listening skills are as follows:

a) Poetry paves the way for teaching the target language culture.

b) It enables students to go beyond what is written and dive into what is meant.

c) It brings authenticity into the classroom.

d) It gives students the opportunity to make use of their creativity.

e) It heightens effective listening skills.

These are some of the factors to enrich the speaking knowledge of the students.

The fifth variable which develops the language of the students, out of 120 respondents, 20 are strongly agreed while 40 disagree. 20 


\section{Conclusion}

Literature is an authentic tool to impart speaking skills. It helps the students to speak with others. Poetry is the tool with which the students can achieve their target. They learn various words, diction, and literary terms only by involving into that. To establish poetry in the classroom, teacher has to implement new methods and approach to the students. Speaking practice can be given to them then and there to make them more confident. Students have to involve in all types of activities conducted in the classroom so that they can feel free to share their concept. Motivation of the teacher is important to the enhancement of the students. As a result, they face the spectators without any tension. Poetic words need to be used always when they communicate with others. Thus, teaching poetry as a genre in the classroom makes the students think innovatively and become confident speakers in the society.

\section{References}

[1] Antony, Teaching of English, Chennai, Kavyamala Publishers, (2012).

[2] Brumfit C \& Cater R, Literature and Language Teaching, Oxford: Oxford, (2013).

[3] Chireev AI, "Developing Speaking Skills in the Secondary English Classroom", English Teaching: Practice and Critique, Vol.5, No.3, (2006), pp.127-136.

[4] Collie \& Slater S, "Literature Classroom: A Resource Book of Ideas and Communication Skills", Contemporary Discourse, Vol.3, (2012), pp.89-94.

[5] Ilankumaran M \&Venugopalan P, "Creative Thinking in Creative Language Classroom", Reading Horizons, (2015), pp.1-4.

[6] Mittal R, Teaching English through poetry: A powerful medium for learning second language. IOSR Journal Of Humanities And Social Science 19 (5) (2014) 21-23.

[7] Ronald C \& Michael N, Teaching Literature, Longman Group UK Second Language, Vol.19, (2014), pp.21-23.

[8] Stephen E \& Firkins A, Dramatizing poetry in the second language classroom, English Teaching, (1996).

[9] Patki LAS, Development of Speaking Skills through Literature, Confluence, (2013), pp.22-23.

[10] Bright C. Technology of Teaching English, Chennai: PDR Publishers, (2005), 1-5.

[11] Kershner R, "Developing Students' Teachers Understanding of Strategies for Teaching Children", Education Today, Vol.4, No.50, (2000), pp.31-39.

[12] Kohli AL, Techniques of Teaching English in the New Millenniui, Macmillian Publishers, (2009).

[13] https:/www.brainyquotes.com>quotes 